\title{
Mitigating the South African retirement-income shortfall crisis
}

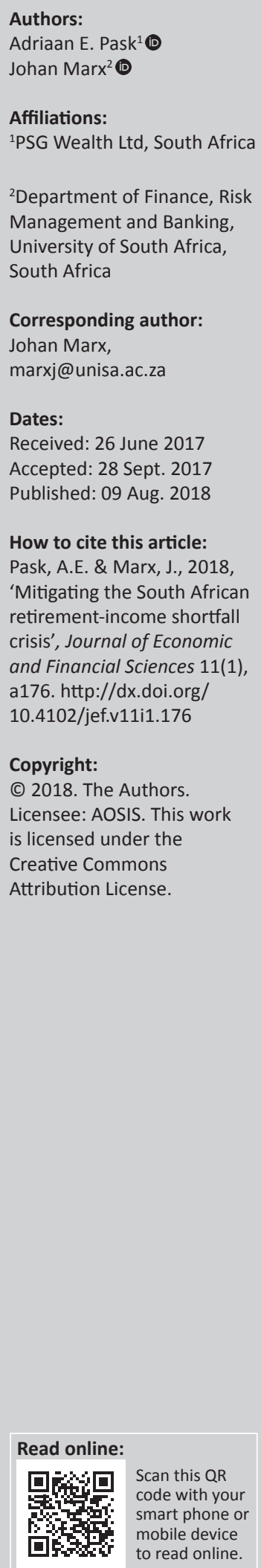

Orientation: National Treasury acknowledges that $90 \%$ of all South African retirees will not have adequate financial resources in order to sustain themselves.

Research purpose: This study aimed to address the retirement income shortfall by assessing possible changes to prudential retirement fund regulations.

Motivation: Asset allocation plays a pivotal role in achieving the required rate of return of any portfolio. However, the restrictions on asset allocation imposed by article 28 of the Pension Funds Act of 1956 limits pension funds' ability to achieve adequate returns.

Research approach: A survey was conducted among chief investment officers (CIO) of the top 25 South African investment management companies.

Main findings: The study proposes changes to the Income Tax Act, the Collective Investment Scheme Control Act and Regulation 28 of the Pension Funds Act.

Managerial implications: The proposed framework should result in fewer pensioners becoming dependent on the state for their pension and empower pensioners to have greater amounts of post-retirement savings.

Contribution: The contribution of this article is the proposed changes to the regulatory framework, which could - ceteris paribus: (1) Enable SA retirement fund investors to contribute to the retirement wealth pool in an unconstrained manner. (2) Enable SA retirement fund assets to increase investment returns by as much as $1.21 \%$ per annum. (3) Increase the average SA GRRs from the current projected $10.0 \%$ to $10.7 \%$ by 2045. (4) Increase the efficacy of the existing tax incentives. (5) Reduce spending requirements for grants in the national budget.

\section{Introduction}

The South African National Treasury acknowledged that only $10 \%$ of South Africans will be able to maintain their preretirement level of consumption after retirement (National Treasury 2012a). Pensioners often find themselves unable to sustain themselves over the full period from retirement up to death because of insufficient funds.

The issue stems from various factors relating to personal spending and budgeting to more complex issues on a macro- or socio-economic level.

Personal spending and budgeting habits that cause retirement funding shortfalls may include, but are not limited to, one or more of the following: firstly, insufficient accumulated funds at the time of retirement because of either saving too little (WorldatWork 2009) and/or saving too late (Edelstein 2013) and/or not saving frequently enough (Van Rensburg 2013); secondly, personal spending and budgeting habits that cause retirement funding shortfalls may be caused by excessive withdrawals (Barclays Wealth 2013); and, lastly, personal spending and budgeting habits that cause shortfalls may be caused by insufficient investment return growth before or after retirement because of poor investment decisions (McGrady Financial 2011).

Macro- and socio-economic issues that cause retirement income shortfalls may include, but are not limited to, inflation (Bermuda Sun 2012) and/or increased longevity [Pfau 2014; South African Medical Research Council (SAMRC) 2015] and/or industry and regulatory impact factors (including insufficient investment growth before or after retirement because of suboptimal regulations within the financial services regulatory environment) (Organisation for Economic Cooperation and Development [OECD] 2012; Pfau 2014). 
The majority of factors relating to personal spending and budgeting habits relate to personal retirement planning and are issues that could potentially be addressed by way of an appropriate retirement plan, assuming the regulatory framework allows for efficient flow into retirement fund vehicles (PI Financial 2013).

Personal spending and budgeting may be improved by equipping individuals with knowledge about personal financial management (Masilo \& Marx 2016). According to National Credit Act Info (2012), retirement, changes in the labour market and personal income are some of the reasons why individuals should learn about personal finance. Retirement planning has become more crucial with the nature of employment changing in the developing open economy (Viswanand 2013). Job security and the notion of work keep on changing. Self-employment has increased, and contractual employment has become more common as it has productivitylinked terms of employment (Viswanand 2013). The individual's personal financial knowledge coupled with his or her goals, income and desire will all combine to define that person's wealth picture (Wealth-Steps.com 2012).

The above-mentioned causes of retirement income shortfalls may be summarised as indicated in Figure 1.

There is currently no research available that specifically relates to how a prudential regulation framework for receiving capital and allocating these funds to various asset classes (specifically within financial products that focus on retirement provision) could combat retirement income shortfalls. The purpose of the study was to provide a solution to the retirement income shortfall as far as the prudential regulatory framework is concerned.

A survey was conducted among chief investment officers (CIOs) in order to assess whether they were of opinion that South African pensioners could benefit from a revised prudential regulation framework. The study proposes changes to the prudential regulatory framework, and more

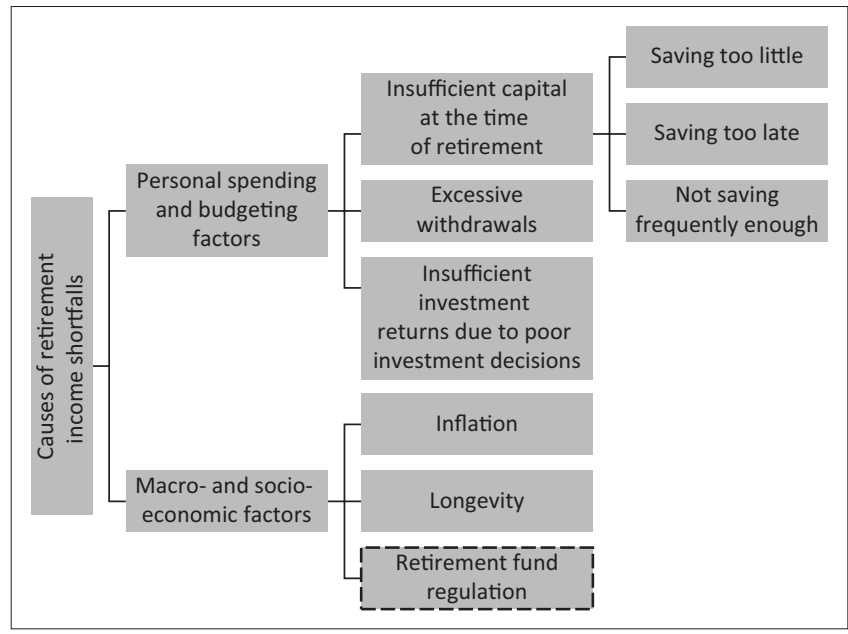

Source: Pask, A.E., 2016, 'A prudential regulation framework to mitigate the South Africa retirement income shortfall crisis', Unpublished PhD thesis, University of South Africa, Pretoria FIGURE 1: Causes of retirement income shortfalls. specifically to the Income Tax Act, the Collective Investment Scheme Control Act and Regulation 28 of the Pension Funds Act. The proposed framework should result in fewer pensioners becoming dependent on the state for their pension and empower pensioners to have greater amounts of postretirement savings.

The consequences of insufficient retirement income are serious. It increases the burden on the fiscal budget and increases the risk of poverty in old age, leaving many dependent on their families, leaving those families with limited savings of their own (National Treasury 2012b).

South Africa will have to increase its retirement fund assets by 5.04 times of the current level if it has to establish a gross replacement rate (GRR) equivalent to that of the average OECD country (Pask 2016).

The remainder of the article is organised as follows. The next section provides the literature review in order to contextualise the study and prove the research gap. The 'Research methodology' section discusses the methodology used in this study. The 'Data analysis and discussion of results' section presents the analysis and the discussion of results, followed by the 'Recommendations' section. Finally, the 'Conclusion' section concludes the article.

\section{Literature review}

The literature review will focus on the relevant aspects of prudential regulation used abroad and locally.

If any regulatory framework allows for efficient flow into retirement fund vehicles, an appropriately qualified specialist may be able to incorporate longevity and inflation projections into the retirement plan in order to ensure that sufficient capital is accumulated prior to retirement to sustain postretirement income requirements (PI Financial 2013).

\section{Environmental changes}

The World Bank (2009) investigated the effect of the 2008 Global Financial Crisis (GFC) on mandatory pension fund systems in emerging economies, with the aim of providing some guidance regarding appropriate and inappropriate steps to be considered following the GFC.

The World Bank (2009) study on the financial crisis and mandatory pension systems in developing countries is important in the context of emerging economies because many of these economies largely rely on mandatory pension systems for retirement income provision (see Figure 2) and are mostly in the process of either introducing reforms or enforcing fairly recent reforms (World Bank 2009). The abovementioned reforms affect asset allocation, volatility, risk of capital loss and long-term wealth creation.

The World Bank (2009) states the GFC reduced asset values in funded benefits and pay-as-you-go (PAYG) schemes, and has 


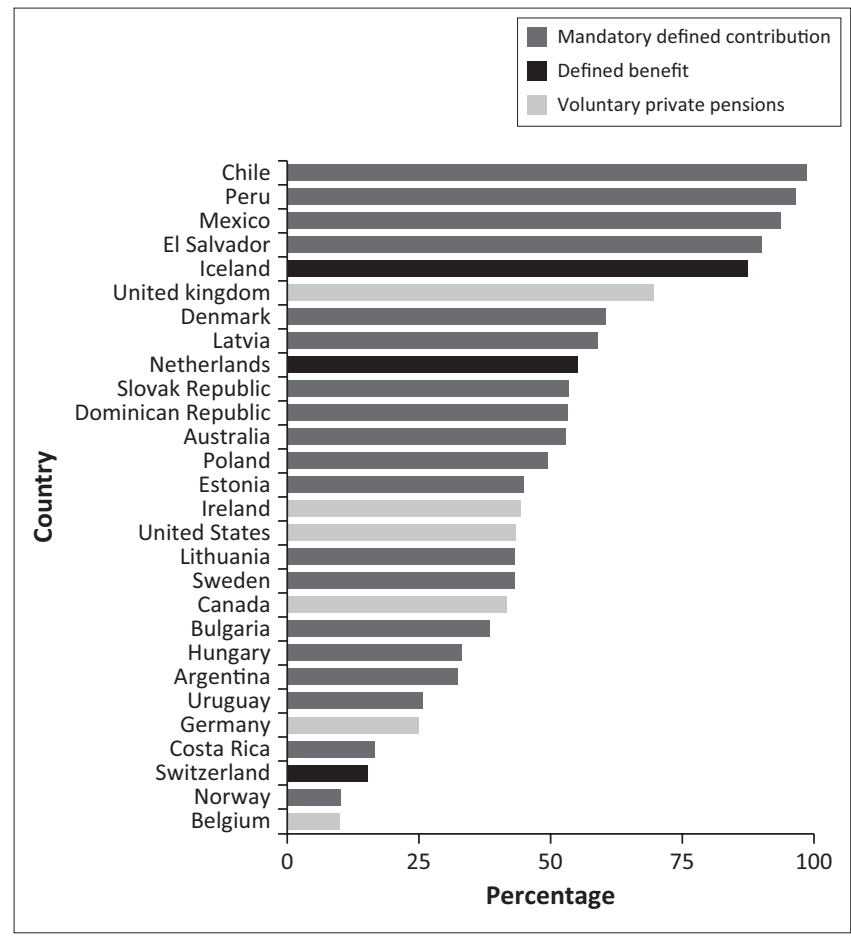

Source: World Bank, 2009, The financial crisis and mandatory pension systems in developing countries, World Bank Press, Washington, DC

FIGURE 2: Pension fund composition of various countries.

also drastically affected the real economy, in particular employment and fiscal revenues. It further shows that although the real pension fund returns for Chile, Mexico, Peru, Uruguay, Hungary and Poland were all negative during the GFC, the long-term real returns for all the aforementioned pension systems were positive and they fluctuated between a real $4.5 \%$ and a real $12.9 \%$ per annum. With these findings in mind, the World Bank suggests that the GFC highlighted the importance of a diversified, multitiered pension system.

\section{Pension fund reforms in South Africa and abroad}

South Africa does not utilise Prudent person regulations, although it could potentially benefit from such regulations. Suboptimal prudential regulations have been disruptive to the effective flow of capital in and out of the retirement fund system (Leape \& Thomas 2011).

Catalan (2004) states that according to conventional wisdom pension reforms, from PAYG systems to fully funded systems, encourage the development of stock markets through additional pension fund investment. It is further stated that considering that the pension funds often become significant shareholders, corporate governance on the listed entities often improves, which then generally results in further endorsement for additional investment from a broader audience (Catalan 2004).

The key findings from the literature show that globally retirement income shortfalls are a common problem (Mercer 2012). Secondly, longevity rates are generally increasing, and this is increasing the future liabilities of pension funds
(Asher \& Vasudevan 2011; Bovenberg \& Meijdam 2001; Commonwealth of Australia 2008; Koekemoer 2012; National Treasury 2012b; OECD 2011; Topoleski 2012). Thirdly, some systems adapt mandatory savings requirements with success, for example, Germany, the Netherlands and Sweden (Mercer 2012), while others do not (South Africa, India and poorer emerging economies) (Asher \& Vasudevan 2011; SASI 2008). It was also found that some systems, like India, are negatively affected by an inequality in the tax regime (Pask 2016).

It was further found that pension funds vary in complexity: some systems (e.g. that of Sweden) are reasonably simple (Palmer \& Larsson 2011), while others (e.g. Japan) are becoming increasingly complex (Sakamoto 2011). It was also found that the areas of taxes, social spending and paternalistic reforms seem to be the more controversial areas of research (e.g. in Chile and South Africa) (Kritzer 2000).

Lastly, the World Bank (2001) found that countries that have adopted Prudent person regulations (e.g. Ireland, the United Kingdom, the United States and the Netherlands) have on average generated higher returns than countries that have not (e.g. Belgium, Sweden, Germany, Japan, Denmark and Switzerland).

As there is currently no research available specifically relating to how a new prudential regulation framework could combat retirement income shortfalls, this article addressed the issue at hand. We will now explain the research methodology.

\section{Research methodology}

The study proceeded from a positivistic paradigm. In addition to the literature review, a survey was conducted among a purposive sample comprising the CIOs of the top 25 investment management companies (in terms of assets under management as at 31 December 2013) in South Africa. Respondents were requested to respond to 15 questions using a 5-point Likert scale as follows:

- Strongly disagree $=1$

- Disagree $=2$

- Neutral =3

- Agree $=4$

- Strongly agree $=5$

The primary objective of the research survey was to establish if there existed a particular view regarding whether a retirement fund's required Regulation 28 compliance affected its ability to generate optimal returns.

\section{Data analysis and discussion of results}

Of the potential 25 respondents, 12 completed and returned the questionnaire, thus providing a response rate of $52 \%$.

A summary of the questions answered and the corresponding results are presented in Table 1 . 
TABLE 1: Summary of research questionnaire results.

\begin{tabular}{|c|c|}
\hline Questions & Average score out of 5 \\
\hline $\begin{array}{l}\text { The current Regulation } 28 \text { is too conservative/restrictive for } \\
\text { most investors' needs }\end{array}$ & 3.1 \\
\hline $\begin{array}{l}\text { The current Regulation } 28 \text { limits a retail investor's ability to } \\
\text { create long-term wealth. }\end{array}$ & 3.5 \\
\hline $\begin{array}{l}\text { The current Regulation } 28 \text { limits asset managers' and other } \\
\text { institutional investors' ability to create long-term wealth for } \\
\text { their clients/investors. }\end{array}$ & 3.5 \\
\hline $\begin{array}{l}\text { The current Regulation } 28 \text { is a contributing cause of } \\
\text { retirement income shortfalls in South Africa. }\end{array}$ & 2.9 \\
\hline $\begin{array}{l}\text { The current Regulation } 28 \text { is not sufficiently actively } \\
\text { adjusted according to market cycles. }\end{array}$ & 2.8 \\
\hline $\begin{array}{l}\text { The Regulation } 28 \text { framework for investing retirement fund } \\
\text { assets should be less focused on managing South Africa's } \\
\text { foreign capital reserves. }\end{array}$ & 3.8 \\
\hline $\begin{array}{l}\text { The Regulation } 28 \text { framework for investing retirement fund } \\
\text { assets should be less focused on managing short-term asset } \\
\text { class volatility. }\end{array}$ & 3.9 \\
\hline $\begin{array}{l}\text { The Regulation } 28 \text { framework for investing retirement fund } \\
\text { assets should be more focused on creating long-term } \\
\text { wealth. }\end{array}$ & 4.1 \\
\hline $\begin{array}{l}\text { The Regulation } 28 \text { framework would be improved if } \\
\text { amended to be cognisant of individual investors' } \\
\text { investment horizons. }\end{array}$ & 3.3 \\
\hline $\begin{array}{l}\text { The Regulation } 28 \text { framework would be improved if } \\
\text { amended to be cognisant of changing asset class valuations. }\end{array}$ & 2.5 \\
\hline $\begin{array}{l}\text { The prudent man regulations applicable to retirement } \\
\text { funds in some developed countries abroad are a more } \\
\text { suitable regulatory approach than Regulation } 28 \text {. }\end{array}$ & 3.4 \\
\hline $\begin{array}{l}\text { The prudent man regulations applicable to retirement } \\
\text { funds in some developed countries abroad are the best } \\
\text { approach to regulating retirement fund investment. }\end{array}$ & 2.9 \\
\hline $\begin{array}{l}\text { South Africa is ready to drastically relax Regulation } 28 \\
\text { restrictions. }\end{array}$ & 2.6 \\
\hline $\begin{array}{l}\text { South Africa is ready to replace Regulation } 28 \text { with the } \\
\text { prudent person regulations. }\end{array}$ & 2.2 \\
\hline $\begin{array}{l}\text { South Africa is ready to replace Regulation } 28 \text { with less } \\
\text { restrictive regulation, but is not ready to replace it with the } \\
\text { prudent person regulations. }\end{array}$ & 3.5 \\
\hline
\end{tabular}

In question 1, respondents were asked whether they believed that the current Regulation 28 is too conservative or restrictive for most investors' needs. Of the respondents, $46 \%$ agreed with the statement, while $39 \%$ disagreed. The remaining $15 \%$ of the respondents had a neutral view. The results suggest that although opinion was relatively balanced, the majority believed that the existing regulations are too restrictive.

In question 2, respondents were asked whether they believed that the current Regulation 28 limits a retail investor's ability to create long-term wealth, to which $69 \%$ agreed with the statement, while $8 \%$ disagreed. The remaining $23 \%$ of the respondents) had a neutral view.

The evidence shows that the majority of respondents had a view that the existing regulation negatively affects investors' ability to create long-term wealth. These findings implicitly support the argument that new prudential regulations could mitigate the retirement income shortfall crisis in South Africa.

In question 3, respondents were asked whether they believed that the current Regulation 28 limits the ability of asset managers and other institutional investors to create long-term wealth for their clients or investors. The survey results showed that $62 \%$ of the respondents agreed with the statement, while $15 \%$ disagreed and $23 \%$ had a neutral view. These results suggest that $62 \%$ of respondents were of the opinion that asset managers and other institutional investors could improve their performance if new prudential regulations are implemented.

In question 4, respondents were asked whether they believed that the current Regulation 28 is a contributing cause of retirement income shortfalls in South Africa. Of the respondents, $46 \%$ agreed with the statement, while $39 \%$ disagreed.

Although the majority of respondents agreed that existing regulation negatively affects investors' ability to create longterm wealth and limits the ability of asset managers and other institutional investors to create long-term wealth, their responses suggest that they fail to make the deduction that the effect of these limitations could ultimately affect the ability of investors to sustain their income needs after retirement.

In question 5, respondents were asked whether they believed that the current Regulation 28 is not sufficiently actively adjusted according to market cycles. Of the respondents, 31\% either agreed or strongly agreed with the statement, while $46 \%$ either disagreed or strongly disagreed, and $23 \%$ of respondents held a neutral view. This evidence suggests that the majority of respondents did not believe that allowing for active management of regulatory asset limits would yield improved results for investors.

In question 6, respondents were asked whether they believed that the Regulation 28 framework for investing retirement fund assets should be less focused on managing South Africa's foreign capital reserves. The majority of respondents (77\%) either agreed or strongly agreed with the statement, while $15 \%$ provided neutral responses and only one respondent indicated that he or she disagreed with the statement. The evidence therefore suggests that the majority of respondents were of the opinion that regulations could be improved by focusing less on South Africa's foreign capital reserves. South African prudential regulations currently limit offshore exposure to $25 \%$ of individual retirement fund assets. The respondents implicitly felt that regulators should focus less on this restriction.

In question 7 , respondents were asked whether they believed that the Regulation 28 framework for investing retirement fund assets should be less focused on managing short-term asset class volatility. Of the respondents, 39\% agreed with the statement and $31 \%$ strongly agreed with the statement, $23 \%$ were neutral and one respondent disagreed with the statement. The evidence therefore shows that $70 \%$ of respondents felt that current regulations are too focused on short-term volatility and that regulations could be improved by focusing less on short-term volatility.

In question 8, respondents were asked whether they believed that the Regulation 28 framework for investing retirement fund assets should be more focused on creating long-term wealth. Of the respondents, $85 \%$ indicated that they either agreed or strongly agreed with the statement. There were 
$15 \%$ neutral responses, and $0 \%$ who disagreed or strongly disagreed.

The survey results of questions 7 and 8 suggest that respondents were of the opinion that a shift in regulatory focus is required, away from short-term volatility towards long-term wealth creation.

In question 9, respondents were asked whether they believed that the Regulation 28 framework would be improved if amended to be cognisant of individual investors' investment horizons. Of the respondents, $46 \%$ agreed or strongly agreed with the statement, while $15 \%$ strongly disagreed with the statement. The remainder of the respondents held a neutral view. These results suggest that the majority of respondents held a view that existing regulations could be improved by being more cognisant of investment horizons.

In question 10, respondents were asked whether they believed that the Regulation 28 framework would be improved if amended to be cognisant of changing asset class valuations. Of the respondents, $62 \%$ indicated that they either disagreed or strongly disagreed with the statement, while $23 \%$ agreed or strongly agreed with the statement and $15 \%$ held a neutral view. Similar to responses recorded in question 5, the evidence suggested that the majority of respondents did not believe that allowing for active management of regulatory asset limits would yield improved results for investors.

In question 11, respondents were asked whether they believed that the Prudent person regulations applicable to retirement funds in some developed countries abroad are a more suitable regulatory approach than South Africa's Regulation 28. Of the respondents, $54 \%$ agreed with the statement, while 39\% held a neutral view. One respondent indicated that he or she strongly disagreed with the statement. These results suggest that the majority of respondents were of the opinion that Prudent person regulations are superior to Regulation 28 of the South African Pension Funds Act (No. 24 of 1956). This evidence suggests that prudential regulations that prioritise personal prudence over regulatory prescription are viewed as more appropriate than prudential regulations that are paternalistic.

In question 12, respondents were asked whether they believed that the Prudent person regulations applicable to retirement funds in some developed countries abroad are the best approach to regulating retirement fund investment. Of the respondents, $15 \%$ agreed or strongly agreed with the statement, while $15 \%$ disagreed with the statement and $70 \%$ of the respondents held a neutral view. This evidence suggests that although respondents were able to express a view on the superiority of one regulatory approach over another (from question 11 above), there was no consensus regarding the ideal regulatory approach to follow.

In question 13, respondents were asked whether they believed that South Africa is ready to relax Regulation 28 restrictions drastically. Of the respondents, $46 \%$ disagreed and $8 \%$ strongly disagreed with the statement, while $15 \%$ agreed with the statement. The remaining $31 \%$ of the respondents held a neutral view. These results show that a large proportion of respondents were opposed to drastic changes in regulation.

In question 14, respondents were asked whether they believed that South Africa is ready to replace Regulation 28 with Prudent person regulations. Of the respondents, 69\% either disagreed or strongly disagreed with the statement. One respondent agreed with the statement and the remaining of the respondents indicated a neutral view. These results show that the majority of respondents did not feel that the Prudent person regulations would be appropriate in South Africa at this stage. These results also indicate that although respondents were of the opinion that the existing prudential regulations which govern asset allocation decisions in retirement funds in South Africa are not ideal, the adoption of this approach implemented in a developed market would be too large a step for South Africa to take at this stage.

In question 15, respondents were asked whether they believed that South Africa is ready to replace Regulation 28 with less restrictive regulation, but is not ready to replace it with the Prudent person regulations. Of the respondents, $54 \%$ agreed and 15\% strongly agreed with the statement. Another 23\% of the respondents disagreed with the statement and $23 \%$ were of neutral opinions. These results again showed that although respondents were of the opinion that the existing prudential regulations which govern asset allocation decisions in retirement funds in South Africa need to be improved, a transition towards the Prudent person approach would not be the ideal approach.

From the above survey results, it can be concluded that respondents were of the opinion that Regulation 28 may restrict investment performance and could benefit from shifting its focus towards less paternalistic constraints.

The survey results also show that although respondents were of the opinion that South Africa is not ready to relax regulations to the extent that Regulation 28 could be replaced by full-discretion Prudent person regulations, South Africa is ready to replace Regulation 28 with less restrictive regulation.

Respondents also strongly felt that the Regulation 28 framework should be less focused on managing short-term asset class volatility and managing South Africa's foreign capital reserves, and more focused on creating long-term wealth.

The shortfalls in the current regulatory framework are three components of prudential regulations: the Income Tax Act, No. 58 of 1962 (as amended), the Collective Investment Scheme Control Act, No. 45 of 2002 (as amended) and Regulation 28 of the Pension Funds Act, No. 24 of 1956 (as amended). In all 
three cases, the efficient capital flow is restricted, which ultimately affects savings and growth potential of the pension fund system.

South Africa already has three market conduct supervisory regulations aimed at the protection of investors, mainly by ensuring that both the distribution of products and the provision of advice are executed in a fair and transparent manner. These are the Retail Distribution Review (RDR); the Financial Advisory and Intermediary Services (FAIS) Act, No. 37 of 2002 (as amended); and the Treating Customers Fairly (TCF) policy. These market conduct supervisory programmes enhance the possibility of implementing a Prudent person approach.

In summary, the data revealed that respondents felt that South Africa could benefit from an amended prudential regulation framework, which would assist the retirement fund system in functioning more efficiently.

\section{Recommendations}

The purpose of this article was, firstly, to identify challenges in the South African retirement landscape; secondly, to examine and assess retirement reforms that are aimed at mitigating retirement income shortfalls (based on the literature review); and, lastly, to identify shortfalls in the current regulatory framework in relation to the South African retirement income shortfall crisis.

Based on the study, a prudential regulation framework is proposed consisting of the following:

- encouragement of uncapped investments into retirement fund vehicles

- the definition of the term 'qualified investor' within the Collective Investment Scheme Control Act, No. 45 of 2002 (as amended) is broadened, and qualified investors are subsequently exempted from Regulation 28 of the Pension Funds Act, No. 24 of 1956 (as amended)

- postretirement withdrawal minimum levels in living annuities to be removed

- once-off withdrawals to be deferred until retirement age

- lump sum withdrawals at retirement to be discouraged, and annuitisation to be encouraged.

Each of these components of the framework will now be explained in greater detail.

\section{Encouragement of uncapped incentivised investments into retirement fund vehicles}

Figure 3 depicts the current cap on encouraged investments into retirement fund vehicles alongside the newly proposed uncapped encouraged investments into retirement fund vehicles.

Based on the findings of the study, it is proposed that the tax deduction cap on retirement fund contributions as described in the Income Tax Act, No. 58 of 1962 (as amended) should be

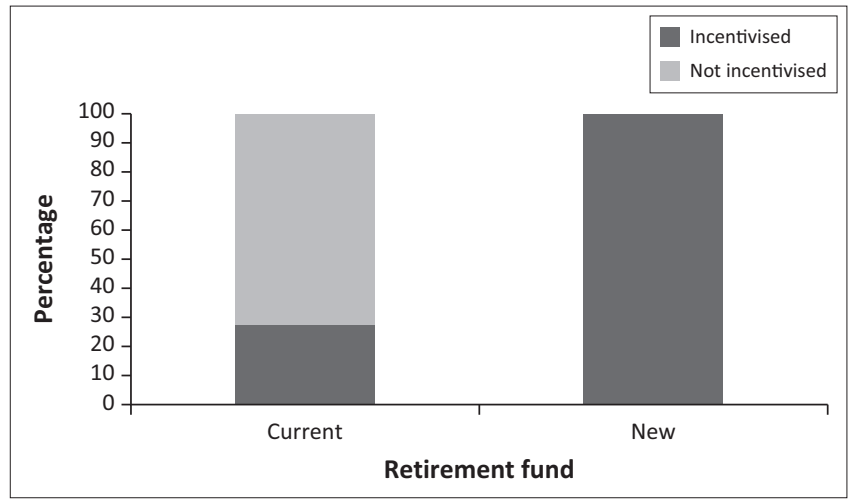

Source: Pask, A.E., 2016, 'A prudential regulation framework to mitigate the South African retirement income shortfall crisis', Unpublished PhD thesis, University of South Africa, Pretoria

FIGURE 3: Retirement fund contribution tax incentives.

phased out. Although the cap that came into effect on 01 March 2016 has been increased to $27.5 \%$, it is proposed that retirement fund members should be able to deduct an uncapped retirement fund contribution from their taxable income (South Africa 1962).

\section{Changes to the definition of 'qualified investor'}

The definition of the term 'qualified investor' within the Collective Investment Scheme Control Act, No. 45 of 2002 (as amended) needs to be broadened to include investors with demonstrable knowledge and experience regarding decisions relating to all Financial Sector Conduct Authority (FSCA)-approved collective investment (not just hedge funds as is currently the case), and qualified investors should subsequently be exempted from Regulation 28 of the Pension Funds Act, No. of 1956 (as amended).

Figure 4 illustrates the effect of the current definition of the term 'qualified investor' within the Collective Investment Scheme Control Act, No. 45 of 2002 (as amended). Figure 5 illustrates the effect of the proposed definition of the term 'qualified investor' within the Collective Investment Scheme Control Act, No. 45 of 2002 (as amended), thereby highlighting the effect of broadening the definition as proposed.

The Collective Investment Scheme Control Act, No. 45 of 2002, defines a qualified investor as any person who (South Africa 2002):

- invests a minimum of R1 million per hedge fund

- has demonstrable knowledge and experience in financial and business matters, which would enable the investor to assess the merits and risks of a hedge fund investment

- has appointed an FSP who has demonstrable knowledge and experience to advise the investor regarding the merits and risks of a hedge fund investment.

Based on this study, it is recommended that the definition of the term 'qualified investor' be broadened to incorporate all FSCA-approved collective investment schemes (CISs), including hedge funds as per the existing definition. A qualified investor is accordingly any person who: 


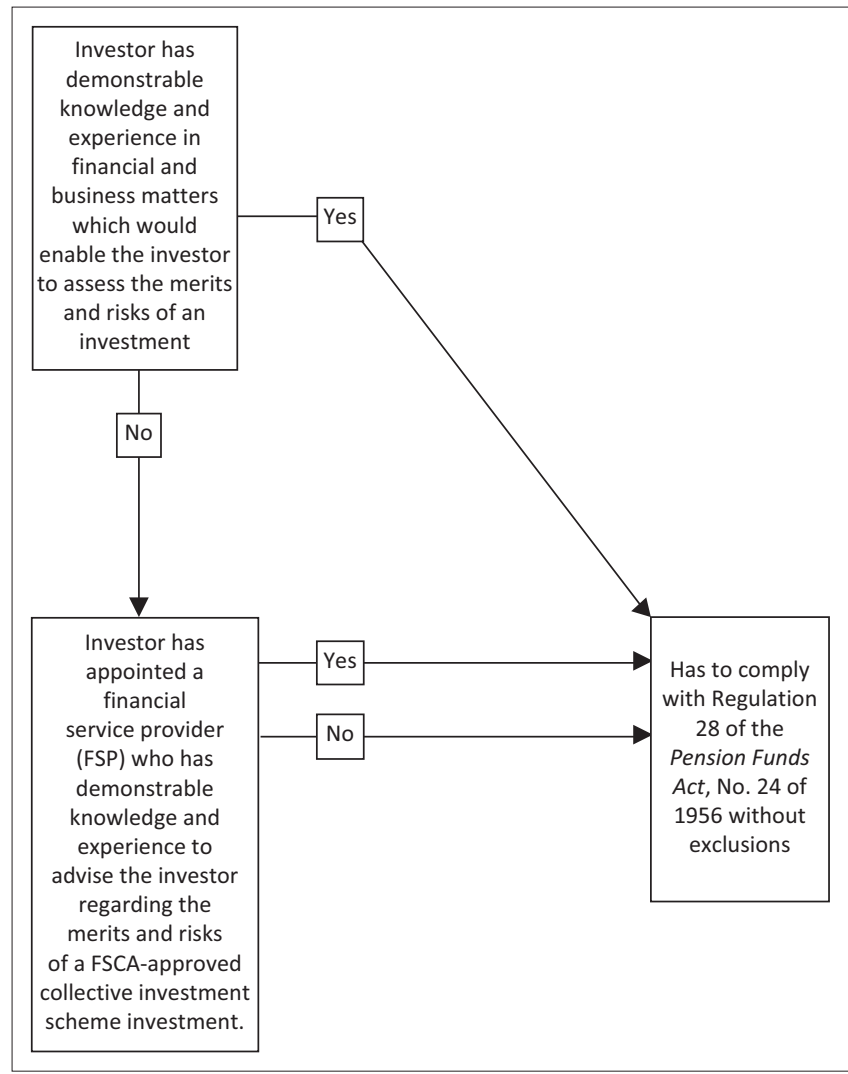

Source: Pask, A.E., 2016, 'A prudential regulation framework to mitigate the South African retirement income shortfall crisis', Unpublished PhD thesis, University of South Africa, Pretoria

FIGURE 4: Effect of the current definition of the term 'qualified investor'.

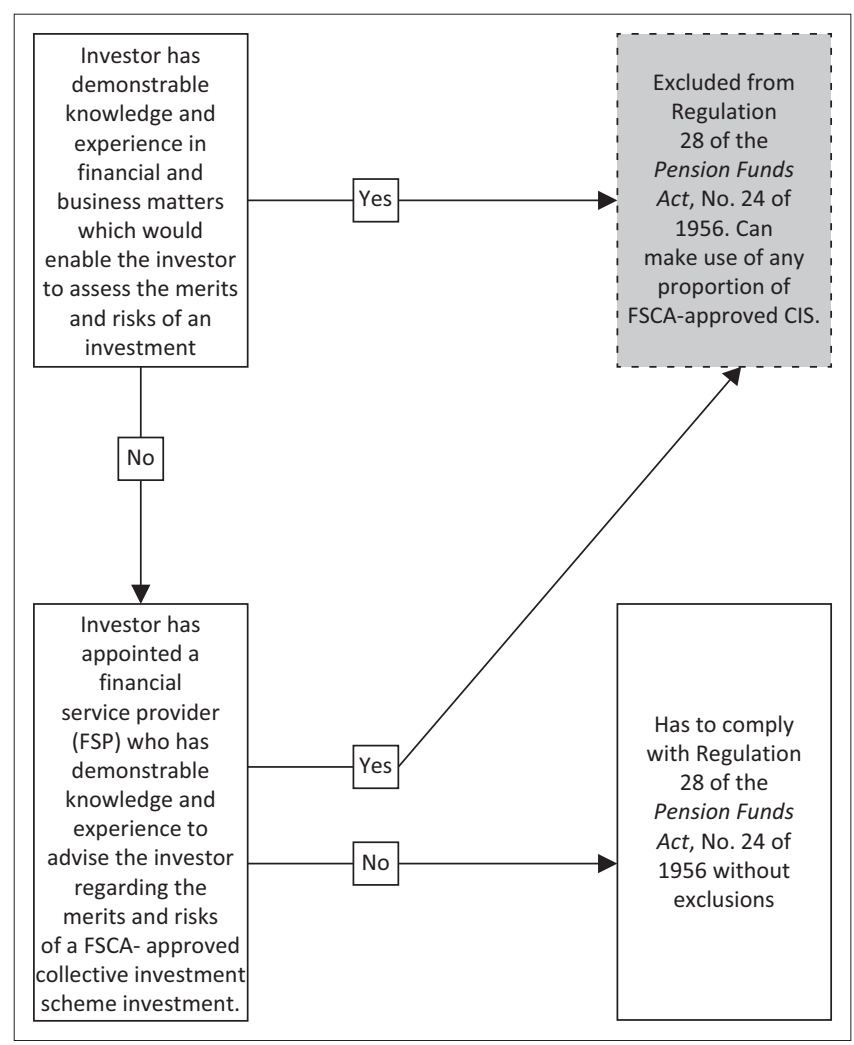

Source: Pask, A.E., 2016, 'A prudential regulation framework to mitigate the South African retirement income shortfall crisis', Unpublished PhD thesis, University of South Africa, Pretoria

FIGURE 5: Effect of the broadened definition of the term 'qualified investor'.
- has demonstrable knowledge and experience in financial and business matters, which would enable him or her to assess the merits and risks of an FSCA-approved collective investment; and/or

- has appointed a financial service provider (FSP) who has demonstrable knowledge and experience to advise the investor regarding the merits and risks of an FSCAapproved CIS investment.

In paragraph 28(9), the existing Regulation 28 of the Pension Funds Act, No. 24 of 1956 (as amended) makes provision for exemptions. Introducing an additional clause to paragraph 28(9), namely Exemptions of the Pension Funds Act, which will exempt assets invested via 'qualified investors' as described within the Collective Investment Scheme Control Act, No. 45 of 2002, is proposed.

The practical implication of this proposal is that retirement funds would be able to allow for an investment in any FSCAapproved CIS, provided the retirement fund member:

- has demonstrable knowledge and experience in financial and business matters, which would enable the investor to assess the merits and risks of an FSCA-approved collective investment

- has appointed an FSP who has demonstrable knowledge and experience to advise the investor regarding the merits and risks of an FSCA-approved CIS investment.

Qualified investors in retirement funds will therefore be able to invest in any proportion of any FSCA-approved collective investment as described within the Collective Investment Scheme Control Act, No. 45 of 2002.

\section{Postretirement withdrawal minimum levels in living annuities to be removed}

Figure 6 shows the current compulsory minimum withdrawal that living annuity investors are required to make each year against the new proposal, which will enable investors to preserve a greater portion of their assets each year.

The proposal further suggests that investors who are currently required to withdraw at least $2.5 \%$ of the capital in their living annuities, as per the Income Tax Act, No. 58 of 1962 (as amended), will have the option to forego an income withdrawal and to preserve savings.

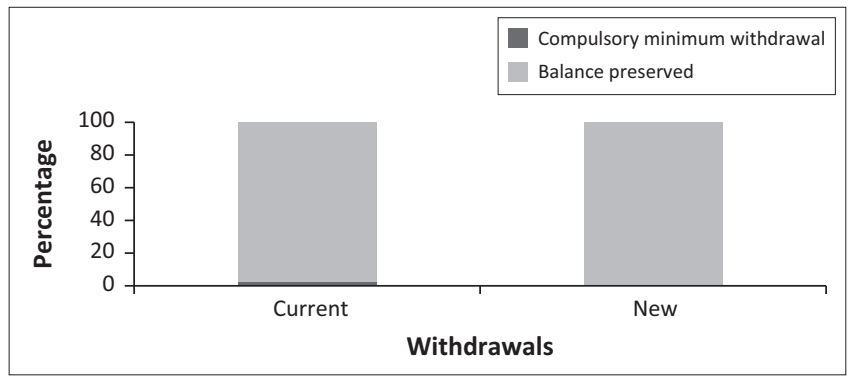

Source: Pask, A.E., 2016, 'A prudential regulation framework to mitigate the South African retirement income shortfall crisis', Unpublished PhD thesis, University of South Africa, Pretoria FIGURE 6: Compulsory minimum withdrawals from living annuities. 


\section{Once-off withdrawals to be deferred until retirement age}

Figure 7 depicts the current allowance on once-off withdrawals from retirement funds prior to retirement versus the new proposal of compulsory preservation prior to retirement.

It is proposed that when a member of a retirement fund resigns from the fund, then the member no longer has the option of taking benefits in cash, but rather should be required to preserve benefits in a preservation fund. Members will no longer be tempted to take benefits early, increasing the probability that they may be able to retire with sufficient savings.

\section{Lump sum withdrawals at retirement to be discouraged and annuitisation to be encouraged}

Figure 8 depicts the proposal to replace incentives to make lump sum withdrawals at retirement with incentives to annuitise and preserve funds.

In this regard, it is proposed that the tax incentive described within the Income Tax Act, No. 58 of 1962 (as amended), which is currently utilised to allow for tax-free withdrawals of up to R500 000 at retirement, should be removed and rather redeployed within the annuitised portion of the retirement benefit in order to promote preservation and annuitisation and not encourage large withdrawals from the retirement fund system.

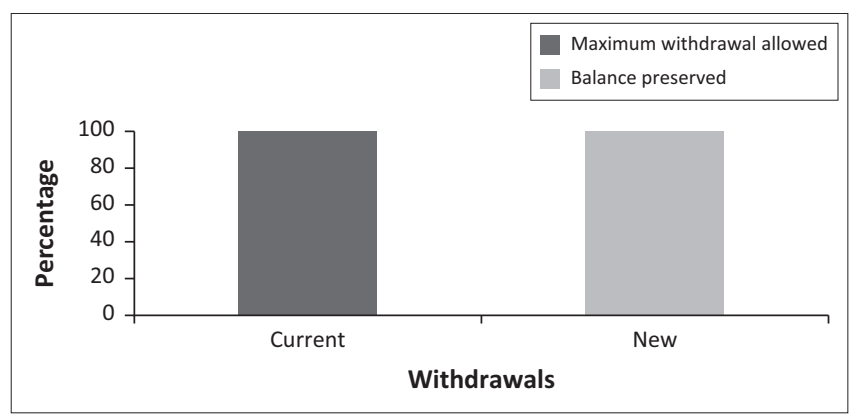

Source: Pask, A.E., 2016, 'A prudential regulation framework to mitigate the South African retirement income shortfall crisis', Unpublished PhD thesis, University of South Africa, Pretoria FIGURE 7: Preretirement withdrawal allowances from a retirement fund.

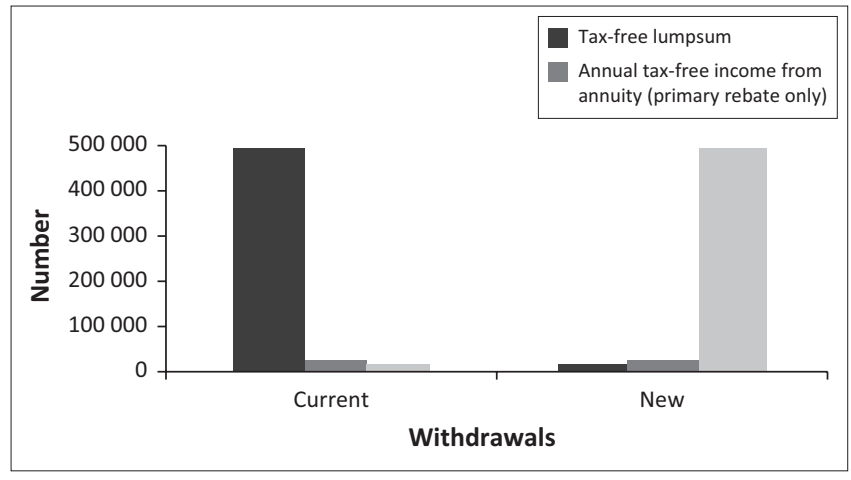

Source: Pask, A.E., 2016, 'A prudential regulation framework to mitigate the South African retirement income shortfall crisis', Unpublished PhD thesis, University of South Africa, Pretoria FIGURE 8: Replacement lump sum withdrawals at retirement.
Because the Income Tax Act, No. 58 of 1962 (as amended) limits annual withdrawals to $17.5 \%$ of the assets, withdrawals will have to be smaller and staggered over time enabling improved preservation.

Some of the benefits of the proposed framework are to:

- contribute towards developing an efficient and sustainable retirement fund industry

- alleviate poverty among the elderly

- reduce the burden on the fiscal budget

- attract investment capital for government and grow the economy

- develop a strategy that could (in part or as a whole) assist the rest of Africa and other countries to combat similar problems.

\section{Conclusion}

South Africa is experiencing a retirement income shortfall crisis. According to the literature, various strategies are available to combat the crisis from a personal spending and budgeting perspective. However, the South African regulatory framework currently constrains capital accumulation and growth. This article proposes an amended framework. There are other countries that have also experienced constrained regulatory frameworks. Liberalised regulatory strategies have been deployed successfully in other countries.

The survey involving the investment industry confirmed that an improved prudential regulation framework could be beneficial to retirement fund investors.

The unique contribution of this article is the proposed changes to the regulatory framework, which could - ceteris paribus:

- Enable South African retirement fund investors to contribute to the retirement wealth pool in an unconstrained manner, which will support capital accumulation in the retirement wealth pool.

- Enable South African retirement fund assets to increase investment returns by as much as $1.21 \%$ per annum. This growth can be accomplished without introducing a significant amount of short-term volatility, and that the proposed strategy would significantly reduce income replacement risk and inflation risk.

- Increase the average South African GRRs from the current projected $10.0 \%$ to $10.7 \%$ by 2045 . The projections presented showed that adopting an investment policy focused on growth would materially increase GRRs over time.

- Increase the efficacy of the existing tax incentives by removing some of the investment constraints associated with retirement fund saving currently applicable. Investors currently perceive the investment restrictions applicable to retirement fund saving as barriers to saving and that these restrictions are counterproductive to the tax incentive structure that is in place in order to promote retirement fund savings. 
- Establish a route to retirement fund saving, which would be free of accumulation and investment allocation restrictions, and improve the efficacy of the existing tax incentives introduced to promote retirement.

- Reduce spending requirements in the national budget. Since 2009, South Africa has exhibited a budget deficit. In addition, the government debt to gross domestic product (GDP) ratio for 2016 was recorded at 51.7\% (Trading Economics 2017).

- Benefit the fiscus from fewer state-dependent retirees who are able to support themselves from their own savings as opposed to making it reliant on the state to fund income shortfalls through welfare spend.

- Promote the development of capital markets by allowing for the free flow of capital as witnessed in other regions globally. Research showed that where policymakers engage in a prescriptive strategy for the allocation of retirement fund capital, such capital may not be invested to optimal use and investors consequently lose faith in the credibility of the retirement fund system.

- Place South Africa on a par with strategies deployed in more developed economies. Research reported earlier showed that developed economies are generally free of retirement fund regulation that is overly prescriptive with regard to asset allocation decisions.

The findings of the present research showed that capital is best allocated in liberalised systems where retirement fund capital can flow to those assets that present retirement fund investors with the best opportunities. Where there are barriers to potentially superior capital allocation opportunities, the quality of capital allocation decisions is compromised.

Reflecting on the results of the study, the following are suggested for future research: quantifying the cost associated with capped incentives on retirement fund investments, compulsory living annuity withdrawals, once-off withdrawals and not annuitising savings at retirement. A study of how investors could best benefit from state-issued securities that are specifically aimed at retirement funding and a study aimed at establishing international best practices for raising and managing retirement funding through state-issued securities and regulations are also suggested.

New prudential regulations could offer a sustainable solution to combat the extent of the retirement income shortfall crisis in South Africa. The $90 \%$ of South African population who will currently not be able to maintain their preretirement level of consumption after retirement will be able to improve their futures.

\section{Acknowledgements}

\section{Competing interests}

The authors declare that they have no financial or personal relationships which may have inappropriately influenced them in writing this article.

\section{Authors' contributions}

A.E.P. and J.M. equally contributed to the research and writing of this article.

\section{References}

Asher, M. \& Vasudevan, D., 2011, 'Market structure and challenges for annuities in India', in O. Mitchell, J. Piggott \& N. Takayama (eds.), Securing lifelong retirement income: Global annuity markets and policy, pp. 32-49, Oxford University Press, Oxford.

Barclays Wealth, 2013, Pension income drawdown, viewed 12 July 2013, from http:// www.barclayswealth.com/private-banking/products-services/retirementprotection/retirement-income-planning/pension-income-drawdown.htm\#

Bermuda Sun, 2012, How inflation can deplete your savings account, viewed 12 July 2013, from http://bermudasun.bm/Content/BUSINESS/Business-Economy/ Article/How-inflation-can-deplete-your-savings-account/72/893/57299

Bovenberg, L. \& Meijdam, L., 2001, Pension reform in six countries: What can we learn from each other? Springer-Verlag, Berlin.

Catalan, M., 2004, 'Pension funds and corporate governance in developing countries: What do we know and what do we need to know?', Journal of Pension Economics and Finance 3(2), 197-232. https://doi.org/10.1017/S1474747204001532

Commonwealth of Australia, 2008, Australia's future tax system: Retirement income consultation paper, CanPrint Communications, Canberra.

Edelstein, W., 2013, It's never too early to start saving for retirement, viewed 12 July 2013, from http://retirementadvice.com/its-never-too-early-to-start-saving-forretirement/

Koekemoer, P., 2012, 'Sustainable income in retirement', Corospondent, October 9-11.

Kritzer, B., 2000, 'Social security privatization in Latin America', Social Security Bulletin 63(2), 17-37.

Leape, J. \& Thomas, L., 2011, Prudential regulation of foreign exposure for South African institutional investors, The London School of Economics and Political Science, London.

Masilo, K.H. \& Marx, J., 2016, 'Assessment of debt counselling services: A case of Gauteng, South Africa', Journal of Economic and Financial Sciences 9(1), 194-208.

McGrady Financial, 2011, A guide to income drawdown, viewed 12 July 2013, from http://www.mcgradyfinancial.com/pdf/draw.PDF

Mercer, 2012, Melbourne Mercer global pension index, Australian Centre for Financial Studies, Melbourne.

National Credit Act Info, 2012, Knowing the importance of personal finance management, viewed 01 May 2013, from http://www.nationalcreditactinfo.co. za/knowing-the-importance-of-personal-finance-management

National Treasury, 2012a, Strengthening retirement savings: An overview of proposals announced in the 2012 budget, Government Printer, Pretoria.

National Treasury, 2012b, Improving tax incentives for retirement savings, Government Printer, Pretoria.

Organisation for Economic Co-operation and Development (OECD), 2011, Pensions at a glance: Retirement-income systems in OECD and G20 countries, OECD Publishing, Paris.

Organisation for Economic Co-operation and Development (OECD), 2012, List of OECD member countries: Ratification of the convention on the $O E C D$, viewed 27 December 2012, from http://www.oecd.org/general/listofoecdmembercountriesratificationoftheconventionontheoecd.htm

Palmer, E. \& Larsson, B., 2011, 'The Swedish annuity market: Where it is and where it's headed', in O. Mitchell, J. Piggott \& N. Takayama (eds.), Securing lifelong retirement income: Global annuity markets and policy, pp. 13-31, Oxford University Press, New York.

Pask, A.E., 2016, 'A prudential regulation framework to mitigate the South African retirement income shortfall crisis', Unpublished PhD thesis, University of South Africa, Pretoria.

Pfau, W., 2014, Retirement risks, viewed 08 October 2016, from http://mcleanam.hssites.com/retirement-risks-download.

PI Financial, 2013, Risks to retirement, viewed 12 July 2013, from http://www. retirementplanningvancouver.ca/risks-retirement

Republic of South Africa, 1962, Income Tax Act, no. 58, 1962 (as amended), Government Printer, Pretoria.

Republic of South Africa, 2002, Collective Investment Scheme Control Act, no. 45, 2002 (as amended), Government Printer, Pretoria.

Sakamoto, J., 2011, 'Annuity markets in Japan', in O. Mitchell, J. Piggott \& N. Takayama (eds.), Securing lifelong retirement income: Global annuity markets and policy, pp. 159-170, Oxford University Press, New York.

South African Medical Research Council (SAMRC), 2015, Rapid mortality surveillance report 2014, The University of Cape Town, Cape Town.

South African Savings Institute (SASI), 2008, Old-age saving by low-income South Africans, viewed 18 may 2014, from www.finmark.org.za\%2Fwpcontent $\% 2$ Fuploads $\% 2$ Fpres oldagesaving.pdf\&ei=kFh7U_JN6nH7Abev4DgAQ\&usg=AFQjCNFY8kl1RkgWgQGh3 wYAJZpoITbA\&bvm=bv. 672292 
Topoleski, J., 2012, '401(k) plans and retirement savings: Issues for congress', in D. Harkin (ed.), Retirement income: Considerations for employees and policymakers, pp. 121-159, Nova Science, New York.

Trading Economics, 2017, South Africa economic indicators, viewed 21 June 2017, from http://www.tradingeconomics.com/south-africa/indicators

Van Rensburg, R., 2013, Pensions shocker, viewed 12 July 2013, from http://www. citadel.co.za/Media/document/You.pdf

Viswanand, V., 2013, Better retirement planning, viewed 15 May 2013, from http://www. thehindubusinessline.com/opinion/better-retirement-planning/article4724678.ece
Wealth-Steps.com, 2012, The importance of personal finance and why you need to get it, viewed 12 April 2013, from http://www.wealth-steps.com/importance-ofpersonal-finance.html

WorldatWork, 2009, Insufficient savings threaten DC plans, viewed 12 July 2013, from http://www.worldatwork.org/adimComment?id=32396

World Bank, 2001, Portfolio limits: Pension investment restrictions compromise fund performance, World Bank Press, Washington, DC

World Bank, 2009, The financial crisis and mandatory pension systems in developing countries, World Bank Press, Washington, DC. 